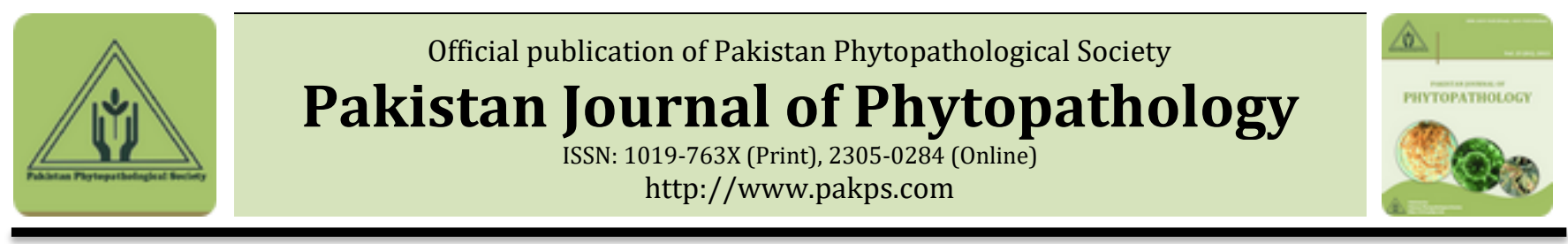

\title{
EVALUATION OF GROUND NUT MATERIAL AGAINST TIKKA LEAF SPOT DISEASE UNDER NATURAL FIELD CONDITIONS AT NARC
}

\author{
aShahzad Asad, aAnjum Munir*, bShah N. Malik, bNazakat Nawaz \\ ${ }^{a}$ Crop Diseases Research Institute (CDRI), Department of Plants and Environmental Protection (DPEP), National \\ Agricultural Research Center (NARC), Islamabad, Pakistan. \\ ${ }^{b}$ National Oilseed Research Program, National Agricultural Research Center (NARC), Islamabad, Pakistan.
}

\begin{abstract}
A B S T R A C T
The ground nut material, (including germplasm, candidate line etc) was planted at NARC in a previously sick field with the objective to check material for resistance against tikka leaf spot disease caused by Cercospora personata. A total of 44 entries were evaluated under four different sets of experiments whereas BARD-479 was included as the check. Among four candidate entries one entry exhibited 1R reaction two were 3MR compared to check which showed 7S reaction. Among the 13 entries of the International Confectionery ground nut trail 5 entries showed $1 \mathrm{R}$ and 5 were showing 3MR reactions whereas two entries exhibited 5MS. Among fifteen entries of NUGYT, six entries were found resistant(R), seven were moderate resistant (MR) while one entry was moderately susceptible (MS). Among thirteen entries of advance medium maturity ground nut yield trail, seven were found resistant (R), four were MR while one entry exhibited MS compared to check which exhibited S reaction. Based on this evaluation it is concluded that 18 entries have exhibited the resistance against Tikka disease whereas BARD-479 (Check) showed susceptible response under natural conditions. The lines showing $1 \mathrm{R}$ reaction can be used in the varietal development.
\end{abstract}

Keywords: Ground nut, Tikka leaf spot, Resistance

\section{INTRODUCTION}

Groundnut (Arachis hypogaea L.) is an important food, feed and oilseed crop. It has high protein $(25-28 \%)$ and oil content (43-55\%) (Naeem et al., 2009). It is grown in nearly 100 countries. In recent times, groundnut is gaining importance as a food crop due to high contents of digestible proteins, vitamins, minerals, phytosterols. First commercial planting of groundnut in Pakistan started in 1949 in Rawalpindi on an area of 400 hectares (Ahmad, 1990). In Pakistan, this leguminous oil seed crop is cultivated in an area of approximately 81.5 thousand ha, with a production of 91.4 thousand tons, $85 \%$ of which is contributed by the Pothohar regions of Punjab, $12 \%$ by KPK (Khyber Pakhtonkhwa), and 3\% by Sindh, Pakistan (Anonymous, 2013). It is subjected to attack of a number of diseases in Pakistan and many parts of the world such as Cercospora leaf spot,

\footnotetext{
* Corresponding Author:

Email: anjums41@yahoo.com

(c) 2017 Pak. J. Phytopathol. All rights reserved.
}

Alternaria leaf spot, Anthracnose (Colletotrichum spp.), Pepper spot and leaf scorch (Leptosphaerulina crassiasca (Rostr.) Pet, Phyllosticta leaf spot, Scab (Sphaceloma arachidis Bitt \& Jenk), Crown rot (Aspergillus niger Tiegh), Fusarium diseases, Charcoal rot (Macrophomina phaseolina Tassi) Goidanich, Rhizoctonia diseases, Black hull (Chalara elegans Nag Raj and Kendrick), Sclerotinia blight and Verticillum wilt (Kokalis-Burelle et al., 1997; Rasheed et al., 2004; Hassan and Shahzad, 2004). This disease causes 32 to $68 \%$ yield losses (Kannaiyan et al., 1992). The damages caused by the disease include defoliation, reduction in number of pods and haulm yield and low seed quality and increased production cost (Brennemen and Culbreath, 2000). In Bangladesh, it is subjected to attack by at least 18 diseases (Bakr and Ahmed, 2009). Among these diseases Tikka disease of groundnut caused by the fungus Cercospora arachidicola synon personata is one of the most economically important diseases. Various strategies have been suggested for the control of the disease, 
however, chemical method is the most efficient and economic way of controlling the disease all over the world (Smith and Littrell, 1980; Culbreath et al., 2002). Considering harmful impact of fungicides on environment and human health, use of alternative methods are necessary. Now a day, control of plant disease by biological means has attained special attention all over the world. Biological control has been proposed as a substitute of chemical control against plant disease (Harman, 2000), however still lot of efforts are needed to develop an effective and authenticated protocol for the use of biological control under field conditions. The most effective way is to hunt the resistant sources. Keeping in view the significance of this disease the groundnut material has been screened under the natural condition where the crop is being planted for many years and the field conditions became the hot spot for the disease.

\section{MATERIALS AND METHODS}

The ground nut material was planted under different sets of experiment at NARC BARD-YARD field area. A total of 44 entries were evaluated under four different sets of experiments. Viz. candidate lines 04 entries (these entries are in the final stage of selection for approval for commercial cultivation), International Confectionery ground nut 13 entries ( these are the exotic entries screened for the resistant source), advance medium maturity 14 entries ( the medium maturity material also in advance stage of selection for commercial cultivation) and National Groundnut Yield Trial (NGYT),15 entries ( the breeders material from all over the country for evaluation for agronomic, breeding and disease parameters), whereas BARD-479 was included as check in all the experiments. The source of this material screened is mostly exotic and received from ICRISAT. All the experiments entries were planted with spacing of $30 \mathrm{cmX} 10 \mathrm{~cm}$. The data was recorded on 0-9 rating scale, as follows:

Scale: $0=$ No Symptoms on leaf, $1=$ Few small necrotic spots covering $1 \%$ or less of leaf area,3= Few small necrotic spots covering1-5\% or less of leaf area, $5=$ Spots coalescing enlarging $6-20 \%$ of the leaf area, $7=$ Spot enlarging, coalescing to cover $21-50 \%$ of the compound of leaf area, $9=$ Spots enlarging, coalescing to cover $51 \%$ or more of the leaf area. (Mayee and Datar, 1986).

The disease development was under natural conditions in a previously sick field was regarded as a hot spot and no inoculations was made.

\section{RESULTS AND DISCUSSION}

Although the disease can also be managed by the use of appropriate fungicides, however, their use is expensive and not readily available to small-scale farmers (Hossain et al., 2007). The development of diseaseresistant cultivars is the most cost effective, and environment friendly solution among all other disease management strategies. The present study aimed to explore the resistance source against Cercospora personata. It is always desired to identify sources of resistance for the development of disease-resistant varieties besides having good yields. Therefore it is useful to identify the area where the experiment was conducted is fenced to avoid wild boar damage to the crop and allocated to the ground nut cultivation since the last twenty years, hence enormous inoculum built up is due to the continuous cultivation of the groundnut in the same area. The diseased plant samples were analyzed for the confirmation of the pathogen. The groundnut variety BARD-479 was included as check that showed the susceptibility rated 7 on $0-9$ rating scale in all the sets of experiments which further confirmed the disease pressure in the field area. Among three candidate entries the entry ICGV-92040 and B4xICGSE-4 was rated as moderately resistant (3MR) while only B4xICGSE-130 showed resistance compared to check. (Table 1). On the basis of the results the candidate line B4xICGSE-4 is recommended for varietal approval. As Mane, (2012) screened a total of 14 groundnut cultivars with 3 check varieties under natural fields conditions. Among this only one variety AK-208-14 showed moderately susceptible reaction while all other cultivars showed susceptible reaction.

Table 1. Evaluation of candidate groundnut entries against Tikka disease under natural field conditions at NARC

\begin{tabular}{llll}
\hline Serial No. & Entries & Disease Severity (0-9) & Reaction \\
\hline 1 & ICGV-92040 & 3 & MR \\
\hline 2 & BARD-479 (Check) & 7 & $\mathrm{~S}$ \\
\hline 3 & B4xICGSE-130 & 1 & $\mathrm{R}$ \\
\hline 4. & B4xICGSE-4 (Short duration) & 3 & $\mathrm{MR}$ \\
\hline
\end{tabular}


Pak. J. Phytopathol., Vol. 29 (01) 2017. 23-27

In the second experiment thirteen entries of the International Confectionery ground nut trial exhibited variable reaction against the disease, five entries each were found resistant and moderately resistant while two entries exhibited moderately susceptible response compared to check that showed susceptibility (Table 2). In our results, the entries having the same back ground of (ICGV) showed resistant to moderately resistant reaction at disease hot spot with the exception of two entries (ICGV-01369 and ICG-4993), which might be due Table 2. Evaluation of International Confectionery groundnut entries against Tikka disease under natural field conditions at NARC.

\begin{tabular}{llll}
\hline Serial No. & Entries & Disease Severity (0-9) & Reaction \\
\hline 1 & BARD-479(check) & 7 & S \\
\hline 2 & ICGV-4993XICGV-90064 & 3 & MR \\
\hline 3 & PG-1188ICGV-01376 & 3 & MR \\
\hline 4 & ICGV-03137 & 3 & MR \\
\hline 5 & ICGV-02234 & 1 & $\mathrm{R}$ \\
\hline 6 & ICGV-02227 & 3 & MR \\
\hline 7 & ICGV-01369 & 5 & MS \\
\hline 8 & ICGV-2511 & 1 & $\mathrm{R}$ \\
\hline 9 & ICGV-6590 & 1 & $\mathrm{R}$ \\
\hline 10 & ICGV-01447 & 1 & $\mathrm{R}$ \\
\hline 11 & ICG-6403 & 1 & $\mathrm{R}$ \\
\hline 12 & PLYF-80-1 & 3 & MR \\
\hline 13 & ICG-4993 & 5 & MS \\
\hline
\end{tabular}

Fifteen National Ground nut Yield Trail entries were evaluated at NARC, among these fifteen entries six were found resistant, seven were moderately resistant while one entry was found moderately susceptible compared to check which showed susceptibility (Table 3). Six lines GN-131127, GN-131121, GN-131116, GN-131111, the reason that these two entries are lacking the resistance against the pathogen. Similar results were also reported by Kalule et al., (2010) that genotype ICGV-SM 03590 and ICGV-SM 02501 from International Crops Research Institute for the Semi-Arid Tropics (ICRISAT) Malawi and SGV AL (Serere Groundnut Variety, advanced line) from NaSARRI having resistance to the disease. Therefore, it was recommended that all the ICG lines showing $1 \mathrm{R}$ reaction may further be used in the development of diseases resistant varieties.

Table 3. Evaluation of National Ground nut Yield Trial (NGYT) entries against Tikka disease under natural field conditions at NARC.

\begin{tabular}{llll}
\hline Serial No. & Entries & Disease Severity (0-9) & Reaction \\
\hline 1 & GN-131127 & 1 & R \\
\hline 2 & GN-131101 & 3 & MR \\
\hline 3 & GN-131121 & 1 & R \\
\hline 4 & GN-131116 & 1 & R \\
\hline 5 & GN-131139 & 3 & MR \\
\hline 6 & GN-131111 & 1 & R \\
\hline 7 & GN-131124 & 5 & MS \\
\hline 8 & GN-131147 & 3 & MR \\
\hline 9 & ICGV-01393 & 3 & MR \\
\hline 10 & PLYF-80-1 & 3 & MR \\
\hline 11 & bard & 3 & MR \\
\hline 12 & 96CG010 & 1 & R \\
\hline 13 & PLYF-80-5 & 1 & R \\
\hline 14 & BARI-2000 & 3 & MR \\
\hline 15 & BARD-479(Check) & 7 & S \\
\hline
\end{tabular}


Among thirteen entries of advance medium maturity ground nut yield trail, six were found resistant, four were found moderately resistant, one entry exhibited moderate susceptibility while two entries were rated susceptible (Table 4). The Advanced medium maturity groundnut lines ICGV-02234, PLYF-80-2, PLYF-80-3, PLYF-80-4, F.557 and ICGV-01395 showed resistant reaction and were recommended for varietal approval. Hossian and Ali (1988) screened 35 lines of ground nut under natural epiphytic condition in Bangladesh and found different reaction of the lines with only one entry found resistant. They included Dhaka-1 as susceptible Table 4. Evaluation of Advance Medium Maturity Ground Nut Yield Trial entries against Tikka disease under natural field conditions at NARC.

\begin{tabular}{llll}
\hline Serial No. & Entries & Disease Severity (0-9) & Reaction \\
\hline 1 & NUNU-2 & 3 & MR \\
\hline 2 & ICGV-01433 & 3 & MR \\
\hline 3 & BARD-479 & 7 & $\mathrm{~S}$ \\
\hline 4 & ICGV-01432 & 3 & $\mathrm{MR}$ \\
\hline 5 & ICGV-02234 & 1 & $\mathrm{R}$ \\
\hline 6 & PLYF-80-3 & 1 & $\mathrm{R}$ \\
\hline 7 & PLYF-80-2 & 1 & $\mathrm{R}$ \\
\hline 8 & JI YOU SI HAO & 3 & $\mathrm{MR}$ \\
\hline 9 & F.557 & 1 & $\mathrm{R}$ \\
\hline 10 & ICGV-01395 & 1 & $\mathrm{R}$ \\
\hline 11 & PLYF-80-4 & 1 & $\mathrm{R}$ \\
\hline 12 & ICGV-97091 & 5 & $\mathrm{MS}$ \\
\hline 13 & BARD-479 (check) & 7 & $\mathrm{~S}$ \\
\hline
\end{tabular}

Where $\mathrm{R}=$ resistant, $\mathrm{MR}=$ moderately resistant, $\mathrm{MS}=$ moderately susceptible, $\mathrm{S}=$ susceptible

\section{REFERENCES}

Ahmad. 1990. Peanut production in Pakistan. A report by Allah dad Ahmed PPD CMPII NWFP Peshawar

Anonymous. 2013. Pakistan Agriculture Research Council. Bakr, M and H. U. Ahmed. 2009. Gradient of oilseed disease management. Advanced in oil seed research in Bangladesh. Proc. Of the Workshop on "Research and development of oil seeds crop in Bangladesh and future challenges". 29-30 April, 2009, BARI, Joydebpur, Gazipur. 170 pp.

Brenneman, T. B. and A. K. Culbreath. 1999. Peanut disease control. In: Georgia Pest Control Hand Book, (eds.) P. Guille beau, The University of Georgia, Special Bulletin 28.

Culbreath, A. K., K. L. Stevenson and T.B.Brenneman. 2002. Management of late leaf spot of peanut with benoyl and chlorothalonil: A study in preserving fungicide utility. Plant Disease, 56: 349-355 check. All together the entries like B4xICGSE-130, ICGV-2511, ICGV-6590, ICGV-01447, ICG-6403, GN131127, GN-131121, GN-131116, GN-131111, 96CG010, PLYF-80-5, had the resistance against Tikka disease where BARD-479 (Check) showed susceptibility under these natural conditions. According to our screening result the above mentioned entries possess considerable resistance and these can be used for further exploitation in the breeding program while the advance and candidate lines showing resistant reaction can be further processed for varietal approval.
Harman, G. E. 2000. Myths and dogma of biocontrol changes in perceptions derived from research on Trichoderma harzianum T-22. Plant Disease. 84(4): 377-393.

Hassan, H.N. and M. K. Beute. 1977 Evaluation of Resistance to Cercospora Leafspot in Peanut Germplasm Potentially Useful in a Breeding Program ${ }^{1}$. Peanut Science: July 1977, Vol. 4, No. 2, pp. 78-83.

Hassan, S.A. and S. Shahzad. 2004. Effect of sea salt on In vitro growth of Sclerotinia Sclerotiorum. Pak. J. Bot., 36(3): 677-782

Hossain, M. D. and M.M.H. Ali. 1988. Screening of groundnut against tikka and rust diseases [in Bangladesh] Abstract: International Information System for the Agricultural science and technology.

Hossain, M.D., M.K. Rehman Abeda and M.M. Rahman. 2007. Screening of groundnut genotypes for leaf 
spots and rust resistance. Int. J. Sustain. Crop Prod 2:7-1

Kokalis-Burelle, N., D.M. Porter, R. RodriguezKabana, D.H. Smith and P. Subrahmanyam. 1997. Compendium of Peanut Diseases. The American Phytopathological Society St. Paul, USA. pp. 1-42.

Kalule.D., C. Deom and N. Puppala. 2010. Screening groundnut acessions for Rossette and Leaf spot Diseases in Uganda. Annual Meetings of ASA, CSSA, SSA, Long Beach, CA - Oct 31 - Nov (abstr.).

Kannaiyan, J., H. C. Haciwa, S. Sithnantham and B. Syamasonta. 1992. Identification of groundnut genotypes less susceptible to early leaf spot in Zambia. IAN. 11:18-20.
Mane, P.A. 2012. Screeening of groundnut cultivars against tikka disease. Asian journal of Bio Science 7(2):189-191

Mayee, C. D. and V.V. Datar. 1986. Phytopathometry. Technical bulletin-1 Marathwada Agricultural University Parbhani.Pp.89.

Naeem-Ud-Din, A. Mahmood, G.S.S. Khattak, I. Saeed and M.F. Hassan. 2009. High yielding groundnut (Arachis hypogea L.) variety "Golden". Pak. J. Bot., 41(5): 2217- 2222.

Rasheed, S., S. Dawar, A. Ghaffar and S. Shaukat. 2004. Seed borne mycoflora of groundnut. Pak. J. Bot. (36(1): 199- 202.

Smith, D. H. and R. H. Littrell. 1980. Management of peanut foliar disease with fungicides. Plant Disease, 64(4): 356-361. 